\title{
Comparison of The Clinical Results of Two Accelerated Ponseti Techniques for Patients with Clubfoot
}

\author{
Çarpık Ayak Hastalarında Iki Hızlandırılmış Ponseti \\ Tekniğinin Klinik Sonuç/arının Karşılaştırılması
}

Ahmet Yigit Kaptan',

Selcuk Korkmazer ${ }^{1}$,

Toygun Kagan Eren ${ }^{2}$

${ }^{1}$ Dr. Sami Ulus Maternity, Child Health and Diseases Training and Research Hospital, Department of Orthopedics and Traumatology, Ankara, Turkey

${ }^{2}$ Ankara Training and Research Hospital,

Department of Orthopedics and

Traumatology, Ankara, Turkey

Geliş Tarihi/Received: 21 January 2021

Kabul Tarihi/Accepted: 23 February 2021

Address correspondence to: Ahmet Yigit Kaptan, Dr. Sami Ulus Maternity, Child Health and Diseases Training and Research Hospital, Department of Orthopedics and Traumatology, Ankara, Turkey

e-mail:dryigitkaptan@gmail.com

ORCID

Ahmet Yigit Kaptan

https://orcid.org/0000-0002-2369-8056

Selcuk Korkmazer

https://orcid.org/0000-0002-4720-9106

Toygun Kagan Eren

https://orcid.org/0000-0002-4526-4216
Öz

Amaç: Hızlandırıımış Ponseti yöntemi, çarpık ayakı hastalara haftalık yönteme göre daha sık aralıklarla manipülasyon ve alçı uygulamasıdır. Bu çalışmanın amacı çarpık ayak hastalarına uygulanan iki farklı hızlandırılmış ponseti yönteminin karşılaştırılmasıdır.

Hastalar ve Yöntem: Eylül 2018 ile Nisan 2020 tarihleri arasında çarpık ayak nedeniyle hızlandırılmış Ponseti yöntemi uygulanan 12 hasta (19 ayak) çalışmaya dahil edildi. Hastalar grup A ve grup B olmak üzere 2 gruba ayrıldı. Grup A haftada iki kez manipülasyon ve alçılama uygulanan hastaları içerirken, Grup B ise ilk gün uygulanan alçılama ve manipülasyon sonrası 2., 3., 4., 5. alçı ve manipülasyonların sırasıyla 4., 5., 6., 7. günlerde yapılan hastaları içeriyordu.

Bulgular: Grup A 6 hastadan ( 9 ayak) ve grup B 6 hastadan (10 ayak) oluştu. Hastaların ortalama yaşları gruplar arasında anlamlı farklılık göstermedi $(P=0,206)$. Pirani skoru son alçı çıkarıldıktan sonra $(P=$ $0.856)$ ve son alçı çıkarıldıktan 6 hafta sonra $(P=0.930)$ gruplar arasında anlamlı farkılık göstermedi. Sonuç: Hızlandırılmış Ponseti yöntemi için belirlenmiş kesin bir aralık bulunmasa da bu çalışmada uygulanan hızlandırılmış Ponseti teknikleri sonucunda başarılı sonuçlar elde edilmiştir.

Anahtar Kelimeler: Çarpık ayak, hızlandırılmış ponseti tekniği, seri alçılama, pirani skoru

\section{Abstract}

Aim: Accelerated Ponseti technique is aplication of manipulation and casting the clubfoot patients more frequent than the weekly technique. The aim of this study is to compare two different accelerated ponseti techniques applied to clubfoot patients.

Patients and Methods: Twelve patients (19 feet) treated with the accelerated Ponseti technique for severe clubfoot between September 2018 and April 2020 were included in the study. The patients were divided into 2 groups as group A and group B. Group A had casting twice a week and Group B had 1st casting in first day of the treatment, with the 2 nd, 3rd, 4 th, 5 th castings in the 4 th, 5 th, 6 th, 7 th day postmanipulation

Results: 6 patients ( 9 feet) were in group A, 6 patients ( $10 \mathrm{feet}$ ) were in group B. There was no significant difference regarding ages of patients' between groups $(P=0.206)$. There were no significant difference between groups regarding Pirani score after final cast removal $(P=0.856)$ and after 6 weeks $(P=0.930)$.

Conclusions: Although there is no definite interval determined for the accelerated Ponseti technique, successful results were obtained as a result of the techniques applied in the present study.

Key words: Clubfoot, accelerated ponseti technique, serial casting, pirani score
Cite this article as: Kaptan AY, Korkmazer S, Eren TK. Comparison of The Clinical Results of Two Accelerated Ponseti Techniques for Patients With Clubfoot. Selcuk Med J 2021;37(1): 1-4

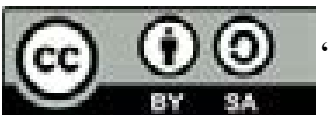

Disclosure: None of the authors has a financial interest in any of the products, devices, or drugs mentioned in this article. The research was not sponsored by an outside organization. All authors have agreed to allow full access to the primary data and to allow the journal to review the data if requested. 


\section{INTRODUCTION}

Clubfoot is an important congenital foot deformity affecting 0.64-6.8 infants per 1000 births (1). When untreated or treated late, it can cause significant disability that affects the patient's mobility, social and educational life. Good results were obtained with the gradual correction of the deformity with the weekly manipulation and casting technique reported by Ponseti, and the surgical release operations performed at an early age were abandoned (2).

In recent years, some authors have reported good results with manipulation and serial casting applied more frequent than the weekly Ponseti technique, but using the same gradual correction technique as the Ponseti reported (3-9). In these studies, successful results are obtained in the early period.

Accelerated Ponseti techniques provide deformity correction in a shorter time and decrease the overall duration of treatment. War and migration still cause serious health problems in some parts of the World (10), and weekly serial casting and manipulation for clubfoot may not always be possible in these regions. Thus, increased compliance to treatment was an expectation as these techniques have provided financial advantages and time savings for families travelling from a long distance. In this study, our aim is to compare the clinical results of two different accelerated Ponseti techniques reported in the literature.

\section{PATIENTS AND METHODS}

Patients who received accelerated Ponseti treatment due to severe clubfoot between September 2018 and April 2020 were included in the study. The study protocol was approved by Dr. Sami Ulus Maternity, Child Health and Diseases Training and Research Hospital, Non-interventional Clinical Trials Ethics Committee (Decision No: 2020-001). Informed consent was obtained from each patient's parents. Patients whose treatment was started in another center, nonadherence to orthosis, secondary, complex, postural and syndromic clubfeet were excluded from the study.

Clinical photographs, Pirani scores and demographic data of all patients who applied to our clinic due to clubfoot were recorded. Two accelerated Ponseti techniques were applied to the patients. Group A had casting twice a week and Group B had 1 st casting in first day of the treatment, with the 2 nd, $3 \mathrm{rd}, 4$ th, 5th castings in the 4th, 5th, 6th, 7th day postmanipulation as reported by Ahmad and Aker (3). We applied Achilles tenotomy and three-weeks casting for each group and documented the Pirani scores after the cast was removed 3 weeks after the Achilles tenotomy and 6 months after the cast was removed.

Denis Browne orthosis was used after the final cast removel and 70 degrees external rotation applied for the effected foot. The parents' of the patients were informed about the orthosis and the use of orthosis for 23 hours in the first 6 months was provided.

\section{Statistical Analyses}

Data analysis was performed using SPSS statistical package version 25.0 (SPS Statistics for Windows, Armonk, NY; IBM Corp.). Normality was defined by using Shapiro-Wilk test. Qualitative variables were presented as numbers and percentages and compared using the Chi-square test. Quantitative variables were presented as median and minumummaximum. Mann-Whitney $U$ test was used to compare mean ranks of two groups. $\mathrm{P}$ value $<0.05$ was considered significant.

\section{RESULTS}

19 feet of 12 patients ( 7 bilateral, 3 left, 2 right) were included in the study. 6 patients ( 9 feet) were in group A, 6 patients (10 feet) were in group B. There was no significant difference regarding ages of patients' between groups $(P=0.206)$. No statistically significant relationship was found between the groups regarding side $(P=0.788)$ and gender $(P=1.000)$. Demographics of the patients are given in Table 1.

All patients in group $A$ and $B$ had severe congenital clubfoot with a Pirani score 6 . Pirani score was evaluated between groups after final cast removal and 6 weeks after final cast removal. The median Pirani score was 0.25 and 0 after final cast removal for group $A$ and $B$, respectively and 0.5 for both groups 6 months after final cast removal. There were no significant difference between groups regarding Pirani score after final cast removal $(P=0.856)$ and after 6 weeks $(P=0.930)$. (Table 2)

\section{DISCUSSION}

Various accelerated Ponseti protocols can be planned to the patients with clubfoot according to their transportation posibilities and living conditions. In the present study we applied two accelerated Ponseti technique to the patients admitted to our outpatient clinic. The main finding of this study is that successful results can be obtained with the accelerated Ponseti techniques in severe clubfoot patients.

Morcuende et al. (4) were the first to report the 
Table 1. Demographics of the patients

\begin{tabular}{|c|c|c|c|c|c|c|}
\hline \multirow{2}{*}{ Variables } & & \multicolumn{2}{|c|}{ Group A $(n=6)$} & \multicolumn{2}{|c|}{ Group B $(n=6)$} & \multirow[t]{2}{*}{$\mathbf{p}$} \\
\hline & & Median & Min-Max & Median & Min-Max & \\
\hline \multirow[t]{2}{*}{ Age } & & 8.00 & $5.00-45.00$ & 7.00 & $4.00-20.00$ & $0.206^{*}$ \\
\hline & & $\mathrm{n}$ & $\%$ & $\mathrm{n}$ & $\%$ & \\
\hline \multirow[t]{3}{*}{ Side } & Bilateral & 3 & 50.0 & 4 & 66.6 & $0.788^{* *}$ \\
\hline & Right & 1 & 16.7 & 1 & 16.7 & \\
\hline & Left & 2 & 33.3 & 1 & 16.7 & \\
\hline \multirow[t]{2}{*}{ Gender } & Male & 4 & 66.7 & 5 & 83.3 & $1.000^{* *}$ \\
\hline & Female & 2 & 33.3 & 1 & 16.7 & \\
\hline
\end{tabular}

${ }^{*}$ Mann-Whitney U test, ${ }^{* *}$ Fisher-Exact test \& Pearson- $\mathrm{X} 2$ cross-tabs

results of accelerated Ponseti technique. They compared the results of standart and accelerated technique applied to 319 clubfeet in 230 patients. They included the patients with previous unsuccesful treatment history and applied casting once in every 5 days for accelerated group. They reported no significant difference between two techniques in terms of average number of casts and rate of relapses in compliant patients. Harnett et al. (5) Elgohary and Abdulsaad (6), Xu (7), Gilani et al. (8) and recently Islam et al. (9) compared the standard Ponseti technique with the accelerated technique applied twice a week. Harnett et al. (5) reported succcesful results in both groups and there were no significant differences between groups in the final post-treatment Ponseti scores. Gilani et al. (8) reported that there was no significant difference between two groups in term of the number of patients with a Pirani score of 1 or less. Xu (7) reported no significant difference between two groups in terms of the number of casts and the number of percutanous achilotomy. Successful results were reported in both groups after an average of 4 years of regular follow-up. Islam et al. (9) reported the immediate post-treatment Pirani scores of 0.34 and 0.35 and Elgohary and Abdulsaad (6) reported of 0.52 and 0.49 in the standart and accelerated (twice a week) group, respectively. Similar to the findings of other studies that applied twice a week casting, the median Pirani score was 0.25 after final cast was removal and 0.50 after 6 months in group $A$ (twice a week) in the present study.
Ahmed and Aker (3) applied accelerated Ponseti technique to 16 clubfeet of 11 patients. Their technique recommends 1 st casting in one day, with the $2 \mathrm{nd}$, 3rd, 4th, 5th castings in the 4th, 5th, 6th, 7th day post-manipulation. They performed achilotomy after the 4th cast and reported the mean Pirani score 0.59 after removal of the three-week cast. We applied the protocol reported by Ahmed and Aker to severe clubfoot patients in this study. However, we modified their technique and prefered to perform achilotomy after the 5th cast to 3 feet in 2 patients. In addition, the mean age of patients in Ahmed et al study was 48.4 days, while the median age of patients in Group $B$ in the present study was 7 days. The median Pirani score after final cast removal and 6 months after cast removal was 0 and 0.50 for Group B, respectively.

Weekly casting and manipulation is the best technique for clubfoot patients. In addition, intervals for the accelerated Ponseti are controversial in the literature. Giesberts et al. (11) stated there is no definite interval for accelerated Ponseti treatment. Morcuende et al. (4) reported that the children were uncomfortable and there was swelling on the medial and superior aspect of the foot when they applied casting 3 to 4 days. We applied the accelerated Ponseti technique only in a limited patient group who cannot attend weekly treatment. We did not observe the complications as reported in the literature, but this may be related to the limited number of patients in the present study.

This study have some limitations. First of all, the

Table 2. Pirani scores after accelerated Ponseti treatment

\begin{tabular}{llllr}
\hline Accelerated Ponseti Group & \multicolumn{2}{c}{ Group A } & \multicolumn{2}{c}{ Group B } \\
& Median & Min-Max & Median & Min-Max \\
\hline Pretreatment Pirani score & 6.00 & $6.00-6.00$ & 6.00 & $6.00-6.00$ \\
After final cast removal & 0.25 & $0.00-1.00$ & 0.00 & $0.00-1.00$ \\
6 months after final cast removal & 0.50 & $0.00-1.00$ & 0.50 & $0.00-1.00$ \\
\hline
\end{tabular}




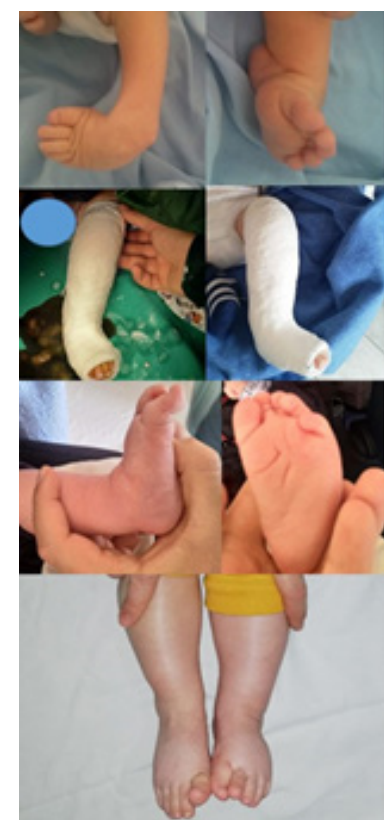

Figure 1. A) Seven day old male patient with left clubfoot. Twice a week (group A) technique was applied to the patient. B) Final cast after achillotomy. C) After final cast removal. D) 6 months after final cast removal

study has retrospective design and limited number of patients. Second, there was no group of patients treated with weekly manipulation and casting. Moreover, the time interval from the beginning of treatment to the achilles tenotomy and the number of casts were not evaluated.

As a result, successful results are obtained with both accelerated Ponseti protocols. Studies with long follow-up time are needed to decide on the appropriate interval when conditions require applying the accelerated Ponseti technique.

Conflict of interest: Authors declare that there is no conflict of interest between the authors of the article.

Financial conflict of interest: Authors declare that they did not receive any financial support in this study.

Address correspondence to: Ahmet Yigit Kaptan, Dr. Sami Ulus Maternity, Child Health and Diseases Training and Research Hospital, Department of Orthopedics and Traumatology, Ankara, Turkey

E-mail: dryigitkaptan@gmail.com

Phone number: (0312) 4123000

\section{REFERENCES}

1. Barker S, Chesney D, Miedzybrodzka Z, et al. Genetics and epidemiology of idiopathic congenital talipes equinovarus. J

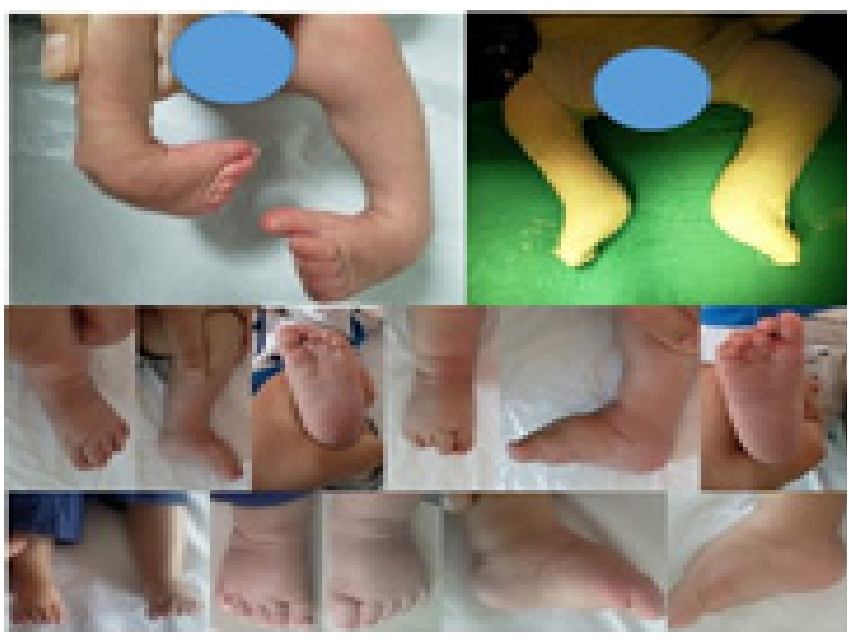

Figure 2. A) 21 day old male patient with bilateral clubfoot in group $B$ before treatment and final cast after achillotomy B) After final cast removal. C) 6 months after final cast removal

Pediatr Orthop 2003;23(2):265-72.

2. Colburn M, Williams M. Evaluation of the treatment of idiopathic clubfoot by using the Ponseti method. J Foot Ankle Surg 2003;42(5):259-67.

3. Ahmad AA, Aker L. Accelerated Ponseti method: First experiences in a more convenient technique for patients with severe idiopathic club feet. Foot Ankle Surg 2020;26(3):2547.

4. Morcuende JA, Abbasi D, Dolan LA, et al. Results of an accelerated ponseti protocol for clubfoot. J Pediatr Orthop 2005;25(5):623-6.

5. Harnett $P$, Freeman R, Harrison WJ, et al. An accelerated ponseti versus the standard Ponseti method: A prospective randomised controlled trial. J Bone Joint Surg $\mathrm{Br}$ 2011;93(3):404-8.

6. Elgohary HS, Abulsaad M. Traditional and accelerated ponseti technique: A comparative study. Eur J Orthop Surg Traumatol 2015;25(5):949-53.

7. Xu RJ. A modified Ponseti method for the treatment of idiopathic clubfoot: A preliminary report. J Pediatr Orthop 2011;31(3):317-9.

8. Gilani SF, Ahmed S, Obaid-Ur-Rehman MAB. Comparison of accelerated VS standard ponseti technique in management of idiopathic clubfoot. Journal of Pakistan Orthopaedic Association 2014;26(1):7-10.

9. Islam MS, Masood QM, Bashir A, et al. Results of a standard versus an accelerated ponseti protocol for clubfoot: A prospective randomized study. Clin Orthop Surg 2020;12(1):100-6.

10. Abbara A, Blanchet K, Sahloul Z, et al. The effect of the conflict on syria's health system and human resources for health. World Health Popul 2015;16:87-95.

11. Giesberts RB, van der Steen MC, Maathuis PGM, et al. Influence of cast change interval in the ponseti method: A systematic review. PLoS One 2018;22;13(6):e0199540. 